Journal of Contemporary Research in Business, Economics and Finance

ISSN: 2641-0265

Vol. 4, No. 1, pp. 1-15.

2022

Publisher: Learning Gate

DOI: $10.55214 /$ jcrbef.v4i1.167

(C) 2022 by the authors; licensee Learning Gate

\title{
Putting People First, a Necessary Change in the Appraisal of Major Infrastructure Projects
}

\author{
Domingo Penyalver* \\ International Centre for Numerical Methods in Engineering, Spain. \\ Email:_penalver@,cimne.upc.edu (*Corresponding Author) \\ Mateu Turro \\ Polytechnic University of Catalonia, Spain. \\ Email:mateu.turro@upc.edu
}

Received: 6 December 202 1; Revised: 10 January 2022; Accepted: 25 January 2022; Published: 4 February 2022

\begin{abstract}
Public decision-makers must ensure that investments make economic sense and are financially sustainable. When privately financed through public-private partnership agreements, a project has to be bankable as well. In the present political setting, an investment is also expected to be analyzed in terms of its contribution to Global Environmental Objectives (GEOs) and Sustainable Development Goals (SDGs). This means producing relevant information on its contribution to environmental sustainability as well as to social and economic progress. Information on the project's redistribution impacts is also relevant in relation to SDGs, but particularly in relation to the UNECE vision of People First. This paper emphasizes the importance of following a rigorous methodology that incorporates these redistribution effects to assess any infrastructure investment. The paper also introduces two concepts -Value for People and Value for the Future - that are key to the evaluation of a project's contribution to socio-economic development.
\end{abstract}

Keywords: Value for people, Value for the future, Sustainable development goals, People first, Public-private partnership $(P P P), E S G$.

\section{Introduction}

Investment in infrastructure is considered a key enabler of economic prosperity and a powerful instrument for addressing social and environmental challenges (Aghion et al., 2013; Foxon et al., 2015; UK-IPA, 2020). Under this premise, governments shape infrastructure development plans, usually following a pre-defined strategy that is aligned with a political stance or specific program (Turro \& Penyalver, 2019). National strategies often pursue the macro-objective of closing the infrastructure deficit in certain regions or territories for the purpose of supporting socioeconomic activity. In the case of Mexico, for example, the federal government has created a "bank of infrastructure projects" to boost the economy of certain areas of the South while simultaneously helping to accelerate the country's economic recovery in the wake of the Covid-19 pandemic. In other cases, infrastructure development plans are pursued to boost certain economic sectors that are considered central to decision-makers. This is, for example, the case in Saudi Arabia, a country that aims to become a global leader in Green Hydrogen production to counteract the decrease in foreign currency from oil sales.

The suitability of infrastructure investments is typically evaluated by weighing the social, economic and environmental costs and benefits directly linked to the project (ADB, 1997; CAF, 2020; DG RegioEU, 2015; Entso-E, 2018; EPA, 2016; HM Treasury, 2018; World Bank, 1997), generally without taking into account the management system and/or funding model that will be used to carry out the 
project. Basically, if the project's benefits outweigh its costs, following the cost-benefit analysis (CBA) methodology, the investment is considered viable, as it means that public resources are being used efficiently (Boardman, Greenberg, Vining, \& Weimer, 2017; Mishan \& Quah, 1976; Turro \& Penyalver, 2019). In principle, this analysis is carried out without regard for which individuals stand to benefit from a project and which will suffer the consequences (Harberger, 1971; Penyalver, 2019). This means that the project appraisal process fails to take into account issues of sustainability, equity or intergenerational fairness, even though they are all fundamental to preserving social and political peace (Galindo, 1963; Turro \& Penyalver, 2019). In light of the present and future challenges the world is facing, concerned associations and individuals, especially of the younger generations, are demanding a change in the way that equity issues and social and environmental targets are ranked within the decisional process of public policies and investment decisions (Mansell, Philbin, \& Konstantinou, 2020).

Following this trend, many decision-makers in the public sector, institutional investors and even some key players in the financial markets are incorporating sustainable development principles and, in particular, Global Environmental Objectives or GEOs (e.g., transition to zero-emissions society) and Sustainable Development Goals or SDGs (e.g., fostering local job creation, overcoming inequalities between men and women, conservation of nature and biodiversity, etc.) in the objectives of their institutions and corporations (Dikau \& Volz, 2020; European Parliament, 2020; Schoenmaker \& Schramade, 2018). In the same vein, the report Transforming Our World: The 2030 Agenda for Sustainable Development highlights that public-private partnership ${ }^{1}$ (PPP) arrangements can be an adequate vehicle for addressing global challenges (poverty, inequality, climate change, environmental degradation, economic growth, etc.). If properly structured, certain PPP arrangements may entice environmentally conscious investors to direct private capital towards sustainable activities that place people at the center of development agendas (United Nations, 2015). Many governments believe that PPPs can be used to spur economic growth and social development while sustaining the well-being of individuals and communities, especially in less developed countries (Cavallo, Powell, \& Serebrisky, 2020). However, this can only occur if PPPs are innovatively designed and adequately implemented.

The incorporation of PPP schemes in major infrastructure plans is not an easy task. Such plans include a fair number of projects that must follow an economic rationale, i.e., be efficient, but must also take into consideration contextual and political aspects that are important to decision-makers (territorial, social and environmental aspects not included in the CBA, availability of funding, management alternatives, macroeconomic constraints, etc.). Hence, it is unclear how the aim of achieving SDGs can be included in the design of such infrastructure plans and their individual projects, particularly those executed through PPPs. In this case, as the focus of the private economic agents is still primarily on return-on-investment and risk analysis, the incorporation of SDG goals, equity issues and intergenerational fairness and justice in the PPP set up and contract negotiations is quite challenging (Galindo, 1963; Penyalver \& Turró, 2018; Poudineh \& Penyalver, 2020).

To incorporate sustainable development principles in the context of infrastructure plans, it is important to overcome the Value for Money (VfM) paradigm of PPPs and to ascertain to what extent the project delivers real value to individuals and communities in the long term (Penyalver, Turró, \& Williamson, 2019). The concept of $V f M$ was introduced by decision-makers to make clear that the financing and management option chosen to carry out necessary infrastructure plans, in particular when opting for PPP arrangements, was the best option to accomplish them efficiently and effectually, according to a development agenda. The concept, which is the most insightful element of a framework conceived for optimizing the use of public resources and money while pursuing the maximization of users' satisfaction with infrastructure and basic services, does not reflect, however, to what extent the project delivers real value to other potential beneficiaries - probably because, beyond the immediate contribution of the investment to local economies (if any), it takes a long time for them and, especially, for taxpayers to achieve $V f M$ (Penny, 2012). Furthermore, the $V f M$ assessment is made up of both

${ }^{1}$ Sustainable Development Goal (SDG) n.17 "Revitalize the global partnership for sustainable development".

Journal of Contemporary Research in Business, Economics and Finance

ISSN: 2641-0265

Vol. 4, No. 1, pp. 1-15, 2022

DOI: $10.55214 /$ jcrbef.v4i1.167

(C) 2022 by the authors; licensee Learning Gate 
objective and subjective perspectives (technical, economic, financial, legal, political, etc.) that cannot be appraised merely in terms of money. Besides, these perspectives depend on the scale (project, portfolio, investment program) and scope (sector, territorial framework) of the appraisal. Consequently, while the VfM approach appears to be a useful way to achieve an adequate balance between efficiency and getting results on time, on the one hand, and minimizing public expenditure on the other, its interpretation is essentially bound to immediate timescales. It is thus important to overcome the $V f M$ paradigm in the appraisal of public investments if SDGs and Paris Agreement targets are to be adopted because they require the project's effects on individuals, communities and the environment to be aligned with the long-term vision of sustainability principles.

Unfortunately, how to move beyond the VfM formula and overcome the focus on return-oninvestment targets while pursuing SDGs and intergenerational fairness is still an open question. Many methodologies $^{2}$ and practical tools ${ }^{3}$ have been developed for economic actors and infrastructure stakeholders to use within their environmental, social and corporative governance (ESG) research, as well as to gauge the "greenness" of investments in infrastructure. Some actors adopt a number of tailored key performance indicators (KPIs) (European Parliament, 2020). Other actors focus on measuring greenhouse gas (GHG) emissions with the aim of establishing to what extent economic activities meet the environmental goals established in the Paris Agreements. However, the current approaches appear insufficient to deliver metrics that evaluate to what extent infrastructure investments, either channeled through typical procurement mechanisms or through PPPs, are aligned with the vision of the United Nations Economic Commission for Europe (UNECE) of putting the people's interests - social, economic and environmental - ahead of market interests, which, by nature, are more focused on the short term rather than on enhancing the welfare of individuals and communities in a sustained way.

From the "people first" perspective, the best way to provide quality infrastructure and services is to invest in projects that somehow exceed the agreed objectives of the decision-maker (generally established in its political program) without leading to unacceptable efficiency losses. Indeed, at the project level, any marginal ${ }^{4}$ increase in avoidable costs (e.g., training local unemployed workers in infrastructure construction or maintenance) should be accepted if it provides additional benefits for nonusers that exceed these costs. If the benefits are difficult to monetize, their comparison with the additional costs should be positive in the context of the main objective of the project, which is the maximization of efficiency for the whole of society in terms of resources. Moreover, the "people first" vision involves some aspects that, as they do not involve additional costs, are not part of the VfM paradigm. For instance, a critical aspect of the people-centered view is to identify the various agents directly involved in the project and establish what the expected effects on them are to ensure that the interests of the general population are respected and placed above purely political and/or market objectives (Penyalver \& Turró, 2018).

The Stakeholders/Effects Matrix ( $S / E$ Matrix) of a project allows for a better understanding of its economic and financial effects, at least on its key stakeholders, as it allows one to check whether the distribution of costs and benefits (in terms of resources) and the money transfers amongst the various agents participating in the project are reasonable or not (Turró, 2004). In addition, the delivery model in general and, in particular, the financing formula chosen to carry out the project have an impact on the relation between the actual costs of its execution, operation, and maintenance, and the benefits garnered over time by the individuals concerned (Penyalver, Turró, \& Zavala-Rojas, 2018). A serious imbalance in this relationship could severely affect some of the objectives included in the initial considerations for

\footnotetext{
${ }^{2}$ For example, the 2 Degrees Investing Initiative (2DII) introduced the concept of aligning investment portfolios with climate objectives through the introduction of the Paris Agreement Capital Transition (PACTA) methodology. The Partnership for Carbon Accounting Financials (PCAF) is the front-runner of this initiative.

${ }^{3}$ For example, the Federation of Civil Engineers Associations of Mexico (FEMCIC) has recently made ENVISION available to its members; this is a platform designed for infrastructure stakeholders to verify in a qualitative manner to what extent infrastructure projects contribute to sustainable development and SDGs.

${ }^{4}$ This refers to a change in the overall expenditure linked to the project that, however, does not affect it in quantity or quality.
} 
the realization of the project, notably those that require relevant periods of time to come to fruition, for example, economic growth, poverty alleviation, inequality reduction, etc. Establishing the project's value for people based upon sustainable development principles thus implies searching for a fair balance over time between the project's net benefits and the concomitant financial burden that users and taxpayers end up bearing as a consequence of the financial structuring of the project (Turro \& Penyalver, 2019).

The remainder of this paper is organized as follows: Section 2 further explores the meaning of the "people first" motto. Section 3 highlights key aspects that infrastructure stakeholders should take into consideration to put people at the center of the process of evaluating infrastructure projects. Section 4 highlights key aspects of public investment appraisal that infrastructure stakeholders must scrutinize to assess whether people's social, environmental and economic interests are being put above other goals that are not always explicit. Section 5 outlines the necessary shift that should take place in investment appraisal to ascertain, in an unambiguous manner, to what extent a particular infrastructure project will deliver real value to people over the years as well as the particular challenges of using PPPs for its implementation. Finally, Section 6 offers concluding remarks and recommendations and highlights a number of points for further discussion.

\section{On the Meaning of the "Putting People First" Concept}

The term "putting people first" has become fashionable. It represents an evolution of the idea of sustainable development introduced by the Brundtland report (Brundtland, 1987). Its clear environmental message has helped policymakers and a considerable part of civil society around the world become aware of the risks of a carbon-based economy (Sachs, 2012). Over the years, the sustainable development paradigm has overcome its original focus on anthropogenic interference in the environment and embraced the so-called triple bottom line approach to human wellbeing, which argues that, beyond pursuing return-on-investment (i.e., profits and shareholders' value), decision-makers should search for synergies between economic development, environmental sustainability and social goals in order to achieve human progress (Sachs, 2012; Slaper \& Hall, 2011). In the first instance, the triple bottom line approach led the international community to agree on the Millennial Sustainable Goals (MSGs), which proved useful in allowing a number of poor countries to make substantial progress in their wellbeing thanks to the financial and technological support of rich countries (Sachs, 2012). The SDGs represent an evolution of the MSGs and aim to replicate the positive results of the MSGs on a broader international scale (Sachs, 2012; Sachs, Schmidt-Traub, \& Durand-Delacre, 2016). In the context of infrastructure development, the term "putting people first" refers to the relevance of developing quality infrastructure and services as a way for countries to improve people's quality of life while pursuing their sustainable development goals.

In the discussion of infrastructure development under the aegis of "putting people first", a major concern is the potential redistribution impact of the participation of the private sector in project financing and management under some type of PPP agreement. Public promotion is essential to deliver basic infrastructure and services to citizens, but governments are often unable to finance major projects because public budgets are increasingly tied up in recurrent expenditure stemming from the operation and maintenance of a growing number of public assets as well as from the increasing costs of social benefits. On the other hand, despite the recent relaxation of macroeconomic constraints following the Covid-19 crisis, the prevention of excessive debt is considered essential to maintaining the creditworthiness (and the resulting borrowing rates) of any country. Given this situation, the public sector thus appears particularly disposed towards joining forces with private investors who are looking for investment opportunities. The abundance of private capital and the fact that interest rates are very low, even negative, provide good opportunities for long-term reliable capital placements, which are particularly relevant for institutional investors (sovereign wealth funds, pension funds, etc.) because the public sector is bound to comply with their long-term commitments. Doing nothing with the resources entrusted to them is not an option, but, on the other hand, they must avoid overly speculative 
investments (Dyck, Lins, Roth, \& Wagner, 2019). So, participating in long-term ventures that harness the safety net of a reliable public partner who is able to spread risk among many projects and who can count, at the end of the day, on the back-up of its taxpayers, offers a very attractive prospect, particularly if the investments have objectives that are in line with the social corporate responsibility goals that are typically included in the statutes of these funds.

For many institutional investors nowadays, but also for other companies, pursuing SDGs and the global transition to a greener economy are objectives complementary to financial returns. This is specially the case of passively managed funds that, by definition, hold a long-term market focus, as they may find business opportunities in investments to energy transition that are disregarded by more speculative funds, which are basically focused on short-term profitability. With a proper assessment of the risks, which is a critical condition for a successful PPP, private investment in major infrastructure projects could provide investors with better returns, over the whole project cycle, than more standard options (Gabor, 2019). In some cases, the public interest of the project, particularly if it plays an active role in mitigating global threats (e.g., the climate emergency, migration, poverty, etc.), may even be a condition for the allocations of the investment fund or a requirement to obtain certain tax exemptions. Such public interest has always been the driver of the activities of Multilateral Development Institutions (MDIs) and International Financial Institutions (IFIs), which must comply with strict eligibility criteria. These institutions require solid business cases for their private borrowers, but they will only finance projects with a clear public interest (Goldsmith \& Turró, 2005). This should, in principle, be guaranteed by the fact that they are publicly promoted projects, though these institutions will increasingly take care of that people's needs are safeguarded when financing PPPs.

The concept of "people first" is easily accepted by decision-makers. However, the main issue regarding its application is how to convert it into something applicable to concrete projects, i.e., how to introduce a measure of quantification that allows comparisons among competing investments. Whilst efficiency has a long, though not particularly successful, tradition of quantification through CBA, ESG factors are still measured at corporate level with ESG labels and ratings that only provide limited benchmarks and quality guarantees to lenders, investors and other infrastructure stakeholders (Gabor, 2019). In addition, double counting is endemic in the current evaluation framework. In any case, assessing an investment's contribution to global warming mitigation or certain social challenges (e.g., decent jobs, inclusive economic growth, gender inequality reduction) may be extremely complicated, as the lack of data is a general problem (Mansell et al., 2020). In other words, most targets related to SDGs and GEOs linked to energy transition cannot be measured quantitatively and unambiguously at project level (AIIB, 2019; European Parliament, 2020). On the other hand, evidence shows that ESG project portfolios do not perform worse than most traditional ones in terms of efficiency and efficacy (Alessandrini \& Jondeau, 2020). Accordingly, the financial industry will be willing to unlock capital for investments in sustainable infrastructure, simply because they can generally expect fair financial returns as compensation for the adopted risk and can, at the same time, demonstrate more corporate responsibility to regulators and stockholders. Furthermore, investing in sustainable infrastructure projects often results in complementary fiscal incentives while maintaining the same performance standards and solvency rules. Put differently, the "people first" flag may be catalytic for investment in ESG project portfolios; however, within the current regulatory context, revamping traditional investment strategies towards greener and social objectives can be also seen as a strategy for "greenwashing" this business sector (Parguel, Benoît-Moreau, \& Larceneux, 2011; Zeidan, 2020), at least in the eyes of the most reproachful part of civil society.

Essentially, it can be argued that the concept of "putting people first" refers to finding a strategy to engage infrastructure stakeholders with local communities in order to develop specific projects in a way that results in win-win solutions, which should ultimately contribute to enhancing the living conditions of persons who are not necessarily users/customers, without efficiency losses. The problem is that the evaluation process for infrastructure investment has normally focused on the infrastructure's users to obtain numerical justification of a project's feasibility, without paying adequate attention to a number of 
redistributive effects that, due to their nature, can endanger the way of life of local communities for years afterward (Freeman \& Groom, 2014; Poudineh \& Penyalver, 2020; Rendall, 2011). On the other hand, although putting people first sounds praiseworthy, it is worth pointing out that in PPP arrangements the public partner - the people, as taxpayers - is bound to take the most critical project risks, notably those deemed as force majeure, upon itself and, in most cases, must ensure sufficient revenues for the private partner (Penyalver et al., 2019). This is particularly the case when the private partner is a Special Purpose Vehicle (SPV) with limited liabilities. An SPV will only be bound by the project's targets and other possible commitments if there are unambiguous metrics in the contract that can support eventual claims by the public sector. These indicators should be part of a continuous monitoring process, capable of highlighting relevant variations of the forecasts, particularly manifestations of the assumed risks, as soon as they appear.

\section{Putting the Vision of "People First" First}

When implementing the "putting people first" framework, decision-makers should ask themselves how the investment strategy itself may be used to deliver social, economic and/or environmental benefits to local communities beyond the project's targets, without taxpayers having to experience unfair financial burdens as a consequence. Reports from IFIs, MDIs and big consultancy firms all maintain that trillions of dollars should be channeled towards infrastructure investment every year to achieve the SDGs by 2050 (especially in low- and middle-developed countries) and to keep the increase in global average temperature to well within $2^{\circ}$ Celsius of pre-industrial levels (a strong commitment of industrialized and wealthy countries). However, those assertions are made for the purpose of catalyzing, at the global level, the diversion of the maximum number of financial resources towards an elusive and, to some extent, ethereal objective linked to a vision of what future civilization should look like. Particularly in developing and less developed countries, major infrastructure projects are simply planned to satisfy users' basic needs. The effects of a project that cannot be properly anticipated, for example, its contribution to the reduction in female unemployment rates, are considered economic externalities ("leaks" of project effects) and, as such, are not taken into account in the CBA. For the same reasons, externalities are found neither in risks analyses nor in financial appraisals, in the case of PPP arrangements. Therefore, the question to be asked is how an infrastructure investment can deliver direct benefits at the local level to people other than the project's eventual users, without incurring new risks or profit reductions for the rest of the project stakeholders, notably the private investors.

Investments that are critical to society (e.g., infrastructure for transport, power supply, sewage infrastructure, telecommunications, basic healthcare, etc.) will only generate real public value as long as the financial burden to be borne by citizens results in useful, reliable and quality infrastructure for the whole of society (Penyalver, 2019; Stough, Vickerman, Button, \& Nijkamp, 2002). Decision-makers are, in this sense, bound to scrutinize to what extent an infrastructure project will be useful to enhance connectivity among citizens whilst removing barriers to access to jobs, markets, information and basic services, both in the short and the long run. On the other hand, as the alignment of a project's targets with green objectives and SDGs is increasingly necessary for infrastructure stakeholders to obtain funding and financing from external sources (World Bank Group, 2020), the project's impacts on society, territory and environment need to be screened, qualitatively, in a more or less standardized way, in order to obtain the distinctive green/sustainable/ESG labels from rating agencies (Gabor, 2019). For the public sector, however, while showing a label indicating a project's "greenness/ resilience/sustainability/adaptability" is not mandatory on an administrative basis, it is worth noting that financing sources alternative to either commercial banks or traditional investment funds may provide funding under better financial conditions, but only if the project's label is "green" enough, and the project is consistent with sustainability principles in general and SDGs in particular (Mansell et al., 2020).

In a formal review process, the economic analysis of the investment is the first milestone to be passed by decision-makers in the public sector (Turro \& Penyalver, 2019). Public servants and political 
leaders are bound to assert that the project will produce socioeconomic benefits higher than its costs (efficiency condition) for the project to make a positive impression on citizens, regardless of who benefits more or less from the investment (Bonnafous \& Masson, 2003) or the financing formula used to carry out the project (Penyalver et al., 2019). The CBA provides indicative metrics on the project's socioeconomic efficiency, although the outcomes cannot be understood as a precise mathematical measure of the project's profitability to society (Thomopoulos, Grant-Muller, \& Tight, 2009). In this methodology, what is relevant is to adequately quantify and economically value the project's costs and benefits, according to the particular context and vision of the region/individuals concerned (Huntington et al., 2019), rather than using unfit references or global parameters to produce values to feed the CBA. On the other hand, economic estimates should always be approached with skepticism, especially when dealing with complex engineering projects and/or when demand forecasts encompass very long timespans. Most forecasts, either of the overall public expenditure linked to the project or its contribution to social, economic and environmental targets, tend to be biased in favor of the project coming to fruition (Flyvbjerg, Holm, \& Buhl, 2002; Flyvbjerg, 2007; Flyvbjerg, 2014).

In addition, to verify the investment's economic sense and the adequacy of the operational and maintenance measures planned for the project's implementation, it is critical to pay attention to the financing mechanism envisaged for building and operating an infrastructure intended to accomplish certain targets linked to SDGs. It could either have recourse to conventional public procurement or be financed through some type of PPP agreement. In a context of heavy public indebtedness, such as that lately driven by the effects of the Covid-19 pandemic, it is difficult to devote budgetary resources to infrastructure; therefore, PPPs can be an adequate instrument to maintain the level of investment in infrastructure, as long as the risk-sharing among stakeholders is appropriately managed (United Nations, 2015). The financial aspects should not, however, be the primary determinants of the use of this alternative mechanism (Penyalver et al., 2019). While PPP arrangements, if properly designed, make sense to optimize the achievement of the multiplicity of sometimes contradictory objectives that are intended to be achieved by a certain project, they entail high transaction costs and may come with substantial political risks and reduce the capacity of future generations to decide on investments (Flinder, 2005). The risks of ending up footing the whole bill (or more) are particularly high when the private sector gets involved in services that "cannot be allowed to fail" (Ashton, Doussard, \& Weber, 2020; Shaoul, 2003).

The second milestone of the PPP scrutiny process is to ensure that lenders and investors, who are willing to risk their own finances to support public infrastructure development, receive an adequate financial return in exchange. This means that such a return must be reasonable and proportional to the risks private investors assume during the process of construction and/or exploitation of the project, as clearly defined in the financial viability analysis. Using the $V f M$ vision to justify PPPs is, however, too narrow, and might be said to have become outdated in the context of the commitments made to SDGs. Essentially, what is important is to complement the project's $V f M$ by including insights on the "people first" vision to advance potential project beneficiaries besides users in the public interest (Chazdon \& Paine, 2014). So, it is not only necessary to ensure compliance with legal rules, regulations and administrative procedures, but also to make decisions on projects in a way that puts people's needs ahead of merely financial interests. In this sense, it is key to ensure transparency and to build confidence in the decisional process through the different stages of the project (preparation, bidding, procurement, construction and implementation/monitoring). It is also important that the professionals embodying the public interest, whether public servants or not, be adequately shielded from illegitimate interests as well as subject to an increased degree of accountability. Furthermore, it is essential for decision-makers to have sufficient know-how and management capabilities to accomplish their tasks efficiently or, if they lack these qualities, to employ staff with the skills and technical capacity to deliver results effectively in collaboration with other firms/organizations (Benington \& Moore, 2010). Much remains to be done to create the proper awareness and to instill best practices and the essential rigor in analyzing and implementing PPP projects (Penyalver et al., 2019; Turro \& Penyalver, 2019); however, the greater the 
social, political and technical legitimacy, transparency and accountability, the higher the acceptance of risk among eventual bidders and the higher the stimulus for competition (Makovšek, 2018). This means that private agents will ultimately ask for a lower risk premium for their involvement in the public initiative.

The decision to carry out the project either through a conventional public procurement or a PPP process must take into account the interests of both citizens and investors; however, there is a necessary pre-condition for any arrangement: sufficient funds, either public or private, must be available for project development and implementation. The financial sustainability of the project must be ensured throughout the construction period and the early operation of the infrastructure. Otherwise, lack of money will result in blockages and the consequent cost overruns and delays that will unavoidably affect the social profitability of the project (Turro \& Penyalver, 2019). This financial scrutiny is, however, particularly relevant when projects are structured through PPPs, as private sector companies bidding for PPP arrangements may only deal successfully with project risks over multi-year spans if they are able to construct an adequate safety net through a number of legal and financial arrangements. Such arrangements must be carefully analyzed by the procurement authority, especially when they support a Special Purpose Vehicle. It has been observed that particularly in the case of extreme events and "black swans", the system of incentives in PPPs has often contributed to a worsening of the financial situation of ongoing projects and a reduction in their chances of survival, ultimately resulting in the taxpayer footing the bill (costs socialization). In our everchanging world, the financial sustainability analysis of projects with long life cycles is not simple, so decision-makers should be aware of the necessity of relying on appropriate professionals (experienced advisors and risks analysts in technical, legal, economic and financial domains) to set up mechanisms to prevent potential revenue shortfalls that would cause the private investor to be unable to fulfill their commitments.

A key analysis to perform when deciding on the procurement model of a public investment is an assessment of the concerns of local communities and taxpayers. The adopted model may have implications for the correlation between the project's positive effects (socioeconomic benefits) and the opportunity costs to be borne by the different social groups, territories and/or generations affected. Infrastructure stakeholders need to be aware that projects with political and social connotations can trigger serious opposition from those groups/territories that feel somehow mistreated if the distribution of the costs and benefits among the agents involved is not balanced. These effects can be observed by means of the Stakeholders/Effects (S/E) Matrix (Turró, 2004), an economic tool that has been proven to offer valuable insights into political and social connotations that are critical to the viability of an investment (Penyalver \& Turró, 2018). For example, in the case of transport infrastructure, the effects of a particular pricing policy on users, service operators, various administrations and, consequently, on groups of taxpayers, can be clearly observed in the synthetic presentation of the S/E Matrix.

Beyond this assessment of the redistribution effects among project-linked stakeholders, adopting the "people first" vision also requires attention to be paid to whether the government's strategy for funding and financing major infrastructure projects will result in a fair balance between the project's net benefits to people and the actual financial burden that the project's users and/or taxpayers will have to cope with over the years (Thacker et al., 2019; Turro \& Penyalver, 2019). It is assumed that PPP arrangements do not directly affect a project's usefulness; there is broad evidence, however, that certain PPP arrangements may have heavy implications for citizens in general and users and/or taxpayers in particular, though they may not be immediately apparent (Ashton, Doussard, \& Weber, 2016; Flinder, 2005). It is thus fair to argue that the best way to safeguard the interests of people when undertaking infrastructure projects is to carry out investments of proven economic efficiency while employing the most appropriate management and financial packages, always paying adequate attention to the social, territorial and environmental equity issues that may arise during the process (Penyalver, 2019). The financial structure of a project is generally designed after the decision to carry out the investment has been firmly established, meaning that its effects in terms of social equity and intergenerational justice are not properly assessed as part of the appraisal process. This practice should be changed to include 
within the pre-evaluation phase of the project an analysis of 1) whether the net benefits directly linked to the particular investment are enough to compensate for the actual financial burden that users and/or taxpayers will have to bear, which can be referred to as the project's Value for People; and 2) whether the financing formula will help to enhance the wellbeing of the successive generations concerned, taking into account the obligations linked to how it will be financed, which can be referred to as Value for Future.

\section{The Necessary Change to Public Investment Appraisal}

Current frameworks for the appraisal of the public value of investments in major infrastructure projects are designed around the assumption that the whole of society benefits from the project's positive effects on users. In addition, the short-term benefits are strongly weighted due to the discounting effect in CBA calculations (Benington \& Moore, 2010). Accordingly, the more users, the greater the public value of the investment, as long as the infrastructure is not congested. The bill that successive generations of taxpayers will have to pay over the years as a consequence of the financial structuring, which often involves distributing investment costs over long periods (usually, decades), passes unnoticed (Penyalver, 2019). This happens because, in many instances, the users do not pay for the full cost of basic infrastructures and services; this is the case, for example, of urban public transport infrastructure, toll-free motorways or renewable energy consumption. As a consequence, public subsidies and/or guarantees are necessary to ensure the project's financial sustainability. Public commitment is particularly complex when the project is channeled through a PPP arrangement. Nevertheless, the eventual opportunity cost for present and future citizens, notably taxpayers, resulting from both the redistribution of wealth due to the project's financing formula and the spending on public subsidies is generally not on the radar of infrastructure stakeholders, possibly because politicians tend to treat these topics as part of a broader fiscal debate (Penyalver \& Turró, 2018), which is mostly framed in the long term.

Engagement with social, environmental and economic priorities that are framed in a more distant future (e.g., poverty reduction, fiscal justice, enhancement of public health, increase in resilience of local communities) is not yet a major concern for infrastructure stakeholders. As explained, the assessment of whether public expenditure or guarantees are needed to ensure the financial sustainability of a project is only carried out when they are required to sustain basic services under PPP schemes. A major assumption of this paper is, however, that decision-makers, institutional investors and other private actors involved in development strategies and/or major investments in infrastructure should explore whether it is feasible to allocate marginal public funds to project investment costs in order to sustain/enhance the living conditions of certain disadvantaged groups and/or local communities, provided that such action will not come with additional risks or reduce the project's profitability to unacceptable levels. If properly planned, such marginal public spending could strategically respond to potential issues that, despite not being relevant to present or future project users, are nonetheless relevant to society, especially when local communities' way of life or future citizens' welfare is at risk due to eventual redistribution effects of a social, territorial or environmental nature.

The contribution of the overall expenditure linked to the project can ultimately be assessed by taking recourse to insights into the project's Value for People and Value for Future, a practice which should be integrated into the evaluation process if the vision of "putting people first" is to be adopted. When a large investment in infrastructure is undertaken, it is indeed important to go beyond the efficiency criterion and, in the case of PPP arrangements, beyond the calculation of Value for Money. In the case of projects that unfold over large timespans, the project's benefits and costs will not be distributed to the same (the present) society, which is the implicit intertemporal perspective of traditional economic/financial tools (Poudineh \& Penyalver, 2020). The assessment of the intergenerational impacts that affect the various generations concerned with a project with a long life cycle may be performed using the Intergenerational Redistributive Effects Model or IREM, which allows the eventual wealth transfers resulting from the project's financial structure to be examined (Penyalver 
\& Turró, 2017; Penyalver et al., 2019; Turro \& Penyalver, 2019). This is particularly useful when aggressive financing programs are on the table, as some generations may benefit noticeably from the project's effects without actually paying for the infrastructure in an equitable manner (Penyalver, 2019) or may have to cope with substantial payments, mostly through taxes, when the risks assigned to the public sector materialize.

The long-term effects that may emerge from financing investment strategies, but also from major infrastructure projects, are typically embedded in the global macroeconomic context (i.e., public deficit and debt), especially at the country level. However, it is also important to generate awareness of the intergenerational implications of infrastructure financing at lower administrative levels. Infrastructure promoters should display proactive behavior towards the welfare of the most vulnerable social groups, such as young and elderly people. It is in this sense that the selection of the most suitable option for financing a major infrastructure project should include a consideration of the fairness of the distribution of costs and benefits among different generations.

In IREM, the intergenerational assessment is carried out under the assumption that all the generations affected by the project have a constant population of identical individuals who hold the same view of the benefits and costs stemming from investment decisions that affect them. This intertemporal perspective is graphically represented in Figure 1 through a sequence of annual generations ${ }^{5}\left(A G_{i}\right)$ that overlap one year, modeled as a succession of standardized weighting curves that reflects the citizens' perspective on the potential contribution of the investment to their quality of life throughout the project's lifespan.

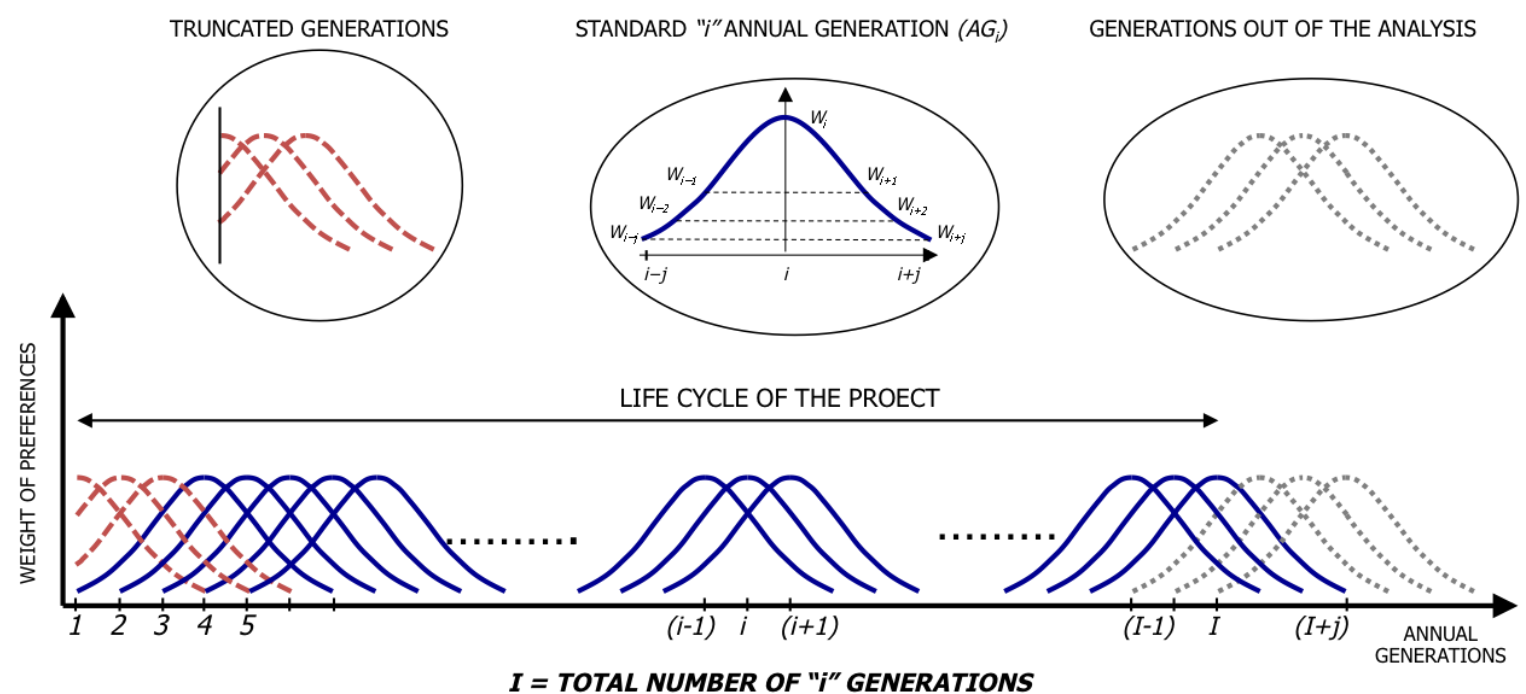

Figure 1.

Generational assessment of the inter-annual differences between costs and benefits.

Source: Adapted from Penyalver (2019).

For the analysis of intergenerational impact, the issue of interest is that, within each annual generation, the project's net benefits and the actual payments that the government promoting the investment has to defray as a consequence of the investment financing may or may not be aligned. Accordingly, some generations may benefit more than they contribute financially while others may end up sharing the financial burden without receiving sufficient net benefits in return. This would imply redistributive effects, which could be substantial, depending on the financial structure that is ultimately

${ }^{5}$ The IREM model assumes that generations overlap one year so that the economy can operate through time in a consistent manner (Penyalver et al., 2018). 
adopted. The assessment of the importance of the intergenerational redistributive effects is only briefly touched upon in this paper, though what is relevant for the concept of "putting people first" is to know that the model produces a number of objective indicators by following a detailed procedure that allows wealth transfers stemming from investment strategies/projects to be looked at closely (cf. Table 1), which is necessary to ultimately arrive at an interpretation in terms of Value for the Future (VfF) according to the intergenerational performance scale outlined in Table 2. The project's VfP and VfF can be obtained independently of the chosen procurement method, as they are based on data from demand studies, economic and financial analyses and risk scenarios used in former stages. However, in the case of PPP arrangements, gathering insights on the project's $V f M, V f P$ and $V f F$ will offer a comprehensive picture of the project's immediate public value alongside information on its alignment with sustainability principles throughout its lifespan.

Table 1.

Analysis of intergenerational impacts: dimensions and general outlines of IREM outputs.

\begin{tabular}{|c|c|c|}
\hline $\begin{array}{l}\text { Dimensions of the analysis of } \\
\text { intergenerational redistribution }\end{array}$ & IREM indicators & Assessment of IREM outputs \\
\hline \multirow{2}{*}{$\begin{array}{l}\text { D1. Intergenerational Utility } \\
\text { The financial strategy finally } \\
\text { adopted by the decision-makers } \\
\text { should sustain the wellbeing of } \\
\text { future individuals. This implies } \\
\text { positive gaps between net benefits } \\
\text { and financial payments (by energy } \\
\text { consumers) for the sets of affected } \\
\text { individuals (grouped in annual } \\
\text { generations) over the period of } \\
\text { reference. }\end{array}$} & $\begin{array}{l}\overline{G A P}: \text { Average value of the } \\
\text { different generational gaps } \\
\left(G A P_{i}\right) \text { obtained along the } \\
\text { period of reference, expressed } \\
\text { in terms of money. }\end{array}$ & $\begin{array}{l}\text { A } \overline{G A P}<O \text { essentially suggests } \\
\text { that the financial strategy } \\
\text { chosen for the implementation } \\
\text { of the project has a negative } \\
\text { impact on most of the affected } \\
\text { generations. }\end{array}$ \\
\hline & 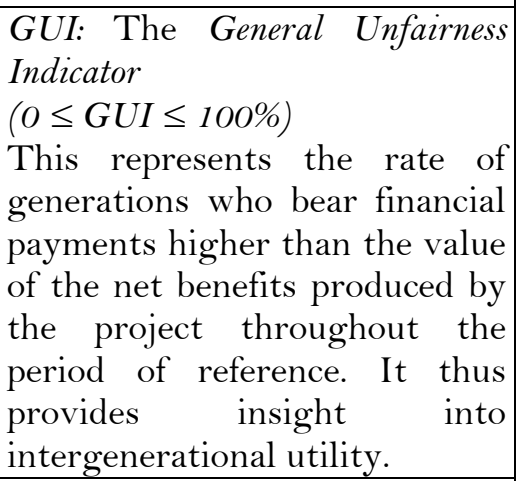 & $\begin{array}{l}\text { Low GUI values indicate that } \\
\text { the number of annual } \\
\text { generations being unfairly } \\
\text { treated (paying more than the } \\
\text { net benefits they obtain) is } \\
\text { small. }\end{array}$ \\
\hline $\begin{array}{l}\text { D2. Intergenerational Performance } \\
\text { The evolution over time of the } \\
\text { effects of the project on the relevant } \\
\text { generations. }\end{array}$ & $\begin{array}{l}T \mathcal{E}^{2}: \text { Trend and Slope (in } \\
\text { grades) of the time series of } \\
\text { the generational gaps } \\
\left(-100 \mathrm{~g} \leq T \mathcal{E}^{2} S \leq+100 \mathrm{~g}\right)\end{array}$ & $\begin{array}{l}T \Xi S>O \text { means that the value of } \\
\text { the successive gaps tends to be } \\
\text { more positive (or less negative). } \\
\text { The higher its value, the more } \\
\text { useful (or less harmful) the } \\
\text { effects of a particular project are } \\
\text { for the future. }\end{array}$ \\
\hline $\begin{array}{l}\text { D3. Intergenerational Redistribution } \\
\text { Redistribution issues may arise if } \\
\text { there are significant transfers of } \\
\text { actual financial charges among } \\
\text { groups of annual generations. }\end{array}$ & $\begin{array}{l}\text { IRESI: The Intergenerational } \\
\text { Redistributive Effects Sharing } \\
\text { Index informs about how } \\
\text { redistribution effects are } \\
\text { shared among generations } \\
\text { over time } \\
(O \leq I R E S I \leq 1 . O O)\end{array}$ & $\begin{array}{l}\text { IRESI tends to } 1.00 \text { if the } \\
\text { differences between the value of } \\
\text { the positive and negative } \\
\text { generational gaps are } \\
\text { significant, which means that } \\
\text { the financial strategy is severely } \\
\text { biased in favor of certain } \\
\text { generations. }\end{array}$ \\
\hline
\end{tabular}

Source: adapted from Penyalver (2019).

Journal of Contemporary Research in Business, Economics and Finance
ISSN: $2641-0265$
Vol. 4, No. 1, pp. $1-15,2022$
DOI: $10.55214 /$ jcrbef.v4i1.167
C) 2022 by the authors; licensee Learning Gate


$V f P$ and $V f F$ insights are necessary for decision-makers and public servants to demonstrate proactive behavior towards the welfare of vulnerable social groups. The impacts of long-term projects on young and elderly people could be substantially different. In terms of $V f F$, a project may entail unexpected opportunity costs for a considerable number of overlapped generations as a consequence of aggressive financing formulas. For instance, the use of bullet loans ${ }^{6}$ may lead to a sudden increase in fiscal pressure, reduction in social benefits, etc. for those generations who are alive during the reimbursement years.

Table 2.

Different cases for the combination of IREM's outputs.

\begin{tabular}{|c|c|c|c|c|c|c|}
\hline \multicolumn{2}{|c|}{ D1. Utility } & \multirow{2}{*}{$\begin{array}{c}\text { D2. } \\
\text { Performance } \\
(\mathrm{T} \& \mathrm{~S}) \\
\end{array}$} & \multirow{2}{*}{\begin{tabular}{|c|} 
D3. \\
$\begin{array}{c}\text { Redistribution } \\
\text { (IRESI) }\end{array}$ \\
\end{tabular}} & \multirow{2}{*}{$\begin{array}{l}\text { Intergenerational } \\
\text { appraisal }\end{array}$} & \multirow{2}{*}{\multicolumn{2}{|c|}{$\begin{array}{l}\text { Intergenerational } \\
\text { performance }\end{array}$}} \\
\hline$\overline{G A P}$ & GUI & & & & & \\
\hline$>0$ & $\approx 0$ & $>0$ & $\approx 0$ & Positive & Fair-balanced & BAL \\
\hline$>0$ & Low & $>0$ & Any & Positive but unbalanced & Fair-unbalanced & UNB \\
\hline$>0$ & High & $>0$ & Low & Positive but unfair & Unfair + & $\mathrm{UF}+$ \\
\hline$\approx 0$ & High & Any & High & Poor and very unfair & Very unfair & VUF \\
\hline$\leq 0$ & High & $<0$ & Any & Negative & Regressive & RGS \\
\hline
\end{tabular}

Aside from the detection of intergenerational imbalances, the use of IREM to explore $V f F$ provides collateral information that may be critical for other objectives linked to the expected evolution of the project and improve investment decisions. For citizens, an increase in the positive gaps between net social, environmental and economic benefits and the financial burden will lead to more vigorous and inclusive economies, whilst a better assessment of the financing impact of investment strategies on taxpayers should result in more stable and balanced public budgets. Ultimately this should have a positive impact on the future of local communities and other citizens, both users and non-users, and, in short, ensure that "people are put first".

Finally, for institutional investors, ensuring adequate $V f P$ and $V f F$ for their projects should be a major driver of their investment strategies, helping to prioritize those with more potential to enhance the living conditions of persons and local communities who are not necessarily users/customers, without having to assume additional risks. Projects that offer a solid economic efficiency and that, in addition, show adequate levels of VfP and VfF could be labeled "financially responsible", thereby enticing third-party financiers to participate in their investment portfolio. Such a label could also be used for improved credit conditions with IFIs and other concerned lenders and, perhaps, to facilitate securitization of bundles of "people first" projects.

\section{Conclusions}

The evaluation process of an infrastructure project's socio-economic viability currently focuses on an assessment of the project's usefulness for users. Generally, if the investment's costs to society can be compensated by the benefits produced by the infrastructure over the project's lifespan, decision-makers will decide to proceed with the investment. However, current project viability assessment methods hardly take into consideration the project's effects on individuals other than users unless there is a strong and immediate impact. In this sense, some redistribution effects (territorial, environmental, social and/or intergenerational), which, by nature, can endanger local communities' way of life for years afterward, tend to fall outside the scope of project analyses conducted either by the public promoter or by private stakeholders with an interest in the investment.

${ }^{6} \mathrm{It}$ is a loan in which the repayment of the entire principal, sometimes even the principal and interest, is due at the end of the loan term. 
This is almost always the case for major projects that have recourse to some types of PPP schemes. Countries with a high level of indebtedness often think that PPP arrangements can be used to spur economic growth and social development while maintaining the wellbeing of individuals and communities. This has led the UN to state that PPP can be an adequate vehicle for addressing global challenges such as SDGs or Paris Agreement targets. The concept of Value for Money (VfM) was developed, in the context of PPP, to optimize the use of public resources and money while pursuing the maximization of users' satisfaction with infrastructure and basic services. $V f M$ is not sufficient, however, to reflect the real value that the project delivers to its beneficiaries who, despite being taxpayers, are not potential users, mainly because the positive outcomes take too much time to come to fruition. The limits of the $V f M$ framework are also marked by the impossibility of obtaining objective indicators to make clear, in an unambiguous manner, whether the investment is aligned with the long-term vision of sustainable principles and ESG considerations. Public decision-makers, but also some other project stakeholders, notably institutional investors, are increasingly concerned about the achievement of SDGs, and $V f M$ seems insufficient to drive their actions.

A major contribution of this paper is its proposal of more adapted indicators for concerned investors and lenders. The concepts of Value for People (VfP) and Value for the Future (VfF) provide basic information on the contribution of development strategies and/or infrastructure projects to sustaining and enhancing the living conditions of both project users and local communities over the years. While they can both be used independently of the procurement method chosen for a project, the information provided by the $V f P$ and $V f F$ analyses is particularly useful for PPP arrangements. In this case, they will offer a comprehensive picture of the project's immediate public value alongside information on its alignment with sustainability principles. Besides, as the indicators of the project's VfF are based on the perspective of the individuals that benefit from or suffer the project's effects over the years, including the financial burden of the investment, they are useful for highlighting the potential risks, notably those related to extreme events such as the Covid-19 pandemic.

The paper provides a framework for the term "putting people first", which was adopted by UNECE and is increasingly used by infrastructure stakeholders, including global institutional investors and international financial institutions. The term lacks a well-established definition, but it refers to the engagement of infrastructure stakeholders with local communities to develop strategies and/or specific projects in a way that results in win-win solutions, in both the short and long run. For the public sector, the term "putting people first" should thus be understood as the best way to provide quality infrastructure and services through an arrangement that somehow exceeds the project's objectives without resulting in a loss of efficiency. For institutional investors, however, it can be better understood as an investment strategy that prioritizes projects with the potential to enhance the living conditions of individuals and local communities who are not necessarily users/customers, without entailing additional risks. For all concerned investors, a common point of this strategy is engagement with projects of solid economic efficiency that in addition are designed to deliver more than the immediate economic benefits to users. Projects that "put people first" could be labeled and eventually pooled in investment portfolios according to objective metrics on their usefulness in sustaining/enhancing the welfare of beneficiaries other than project users over the years. Portfolios of investments identified by means of a "responsible financing" label (a step beyond sustainable finance) could engage socially-concerned third-party financiers to obtain better financial deals and even be securitized.

\section{References}

ADB. (1997). Guidelines for economic analysis of projects. Guidelines (1997), Asian Development Bank, Manila. Retrieved from: https://www.adb.org/documents/guidelines-economic-analysis-projects.

Aghion, P., Besley, T., Browne, J., Caselli, F., Lambert, R., Lomax, R., . . V Van Reenen, J. (2013). Investing for prosperity: Skills, infrastructure and innovation: Centre for Economic Performance, LSE.

AIIB. (2019). Asian ESG enhanced credit managed portfolio ESG framework. Asian infrastructure investment bank. Retrieved from: https://www.aiib.org/en/projects/approved/2018/_download/regional/ESG-enhanced-credit-managedportfolio.pdf. 
Alessandrini, F., \& Jondeau, E. (2020). Optimal strategies for ESG portfolios. Swiss Finance Institute Research Paper, $20-21$. Retrieved from: https://papers.ssrn.com/sol3/papers.cfm?abstract_id=3578830.

Ashton, P., Doussard, M., \& Weber, R. (2016). Reconstituting the state: City powers and exposures in Chicago's infrastructure leases. Urban Studies, 53(7), 1384-1400.

Ashton, P., Doussard, M., \& Weber, R. (2020). Sale of the century: Chicago's infrastructure deals and the Privatization State. Retrieved from: https://metropolitics.org/IMG/pdf/met-ashton-doussard-weber-en.pdf.

Benington, J., \& Moore, M. (2010). Public value: Theory and practice: MacMillan International Higher Education.

Boardman, A., Greenberg, D., Vining, A., \& Weimer, D. (2017). Cost-benefit analysis: Concepts and practice: Cambridge University Press.

Bonnafous, A., \& Masson, S. (2003). Evaluation of transport policies and spatial equity. Journal of Urban Regional Economy, 4, 547-572.Available at: https://doi.org/10.3917/reru.034.0547

Brundtland, G. (1987). Our common future: Report of the world commission on environment and development: Oxford University Press.

CAF. (2020). Analysis of investments in the Latin American land transport sector to 2040. Department of analysis and sector programming. Development Bank of Latin America. Retrieved from: https://www.acyaglobal.com/en/banco-dedesarrollo-de-america-latina-caf-analisis-de-inversiones-en-el-sector-de-transporte-al-2040/.

Cavallo, E. A., Powell, A., \& Serebrisky, T. (2020). From structures to services: The path to better infrastructure in Latin America and the Caribbean. IDB Publications (Books). Retrieved from: https://flagships.iadb.org/en/DIA2020/from-structures-to-services.

Chazdon, S., \& Paine, N. (2014). Evaluating for public value: Clarifying the relationship between public value and program evaluation. Journal of Human Sciences and Extension, 2(2), 100-119.

DG Regio-EU. (2015). Guide to cost-benefit analysis of investment projects. Economic appraisal tool for Cohesion Policy 20142020. Retrieved from: https://ec.europa.eu/regional_policy/sources/docgener/studies/pdf/cba_guide.pdf.

Dikau, S., \& Volz, U. (2020). Central bank mandates, sustainability objectives and the promotion of green finance. SOAS Department of Economics Working Paper Series, Issue Working Paper n.232.

Dyck, A., Lins, K. V., Roth, L., \& Wagner, H. F. (2019). Do institutional investors drive corporate social responsibility? International evidence. Journal of Financial Economics, 131(3), 693-714.

Entso-E. (2018). European cost benefit analysis methodology for grid development projects (ENTSO-E). Retrieved from: https://eepublicdownloads.entsoe.eu/clean-documents/tyndp-documents/Cost\%20Benefit\%20Analysis/2018-10-1 1tyndp-cba-20.pdf.

EPA. (2016). Discounting future benefits and costs. U.S.E.P. Agency; Guidelines for Preparing Economic Analyses. Retrieved from: https://www.epa.gov/sites/default/files/2017-09/documents/ee-0568-06.pdf.

European Parliament. (2020). Regulation (EU) 2020/852 of the European parliament and of the council of June 2020 on the establishment of a framework to facilitate sustainable investment and amending regulation. Official Journal of the European Union (EU) 2019/2088., L 198/13-43.

Flinder, M. (2005). The politics of public-private partnerships. The British Journal of Politics and International Relations, 7(2), 215-239.

Flyvbjerg, B., Holm, M. S., \& Buhl, S. (2002). Underestimating costs in public works projects: Error or lie? Journal of the American Planning Association, 68(3), 279-295.

Flyvbjerg, B. (2007). Cost overruns and demand shortfalls in urban rail and other infrastructure. Transportation Planning and Technology, 30(1), 9-30.

Flyvbjerg, B. (2014). What you should know about megaprojects and why: An overview. Project Management Journal, 45(2), 619.

Foxon, T. J., Bale, C. S., Busch, J., Bush, R., Hall, S., \& Roelich, K. (2015). Low carbon infrastructure investment: extending business models for sustainability. Infrastructure Complexity, 2(1), 1-13.Available at: https://doi.org/10.1186/s40551015-0009-4.

Freeman, M., \& Groom, B. (2014). Positively gamma discounting: Combining the opinions of experts on the social discount rate. The Economic Journal, 125(6), 1015-1024.

Gabor, D. (2019). Securitization for sustainability: Does it help achieve the sustainable development goals? Washington, DC: Heinrich Böll Stiftung North America.

Galindo, E. L. S. (1963). Consideraciones sobre el óptimo de Pareto. El Trimestre Económico, 30(119), 351-358.

Goldsmith, H., \& Turró, M. (2005). The role of international financial institutions in the development of public-private partnerships. Clm. Economy: Castilla-La Mancha Economic Magazine, 6, 231-262.

Harberger, A. C. (1971). Three basic postulates for applied welfare economics: An interpretive essay. Journal of Economic Literature, 9(3), 785-797.

HM Treasury. (2018). The green book: Central government guidance on appraisal and evaluation. Retrieved from: https://www.gov.uk/government/publications/the-green-book-appraisal-and-evaluation-in-central-governent.

Huntington, H. P., Carey, M., Apok, C., Forbes, B. C., Fox, S., Holm, L. K., . . . Stammler, F. (2019). Climate change in context: Putting people first in the Arctic. Regional Environmental Change, 19(4), 1217-1223.Available at: https://doi.org/10.1007/s10113-019-01478-8.

Journal of Contemporary Research in Business, Economics and Finance
ISSN: 2641 -O265
Vol. 4, No. $1, p p .1-15,2022$
DOI: $10.55214 /$ jcrbef.v4i1.167
C 2022 by the authors; licensee Learning Gate


Makovšek, D. (2018). Mobilizing private investment in infrastructure: Investment de-risking and uncertainty. International Transport Forum (OECD/ITF). Retrieved from: https://www.itf-oecd.org/sites/default/files/docs/mobilisingprivate-investment-infrastructure_3.pdf.

Mansell, P., Philbin, S. P., \& Konstantinou, E. (2020). Redefining the use of sustainable development goals at the organisation and project levels-A survey of engineers. Administrative Sciences, 1O(3), 1-39.Available at: https://doi.org/10.3390/admsci10030055.

Mishan, E., \& Quah, E. (1976). Cost-benefit analysis (Vol. 454). New York: Praeger.

Parguel, B., Benoît-Moreau, F., \& Larceneux, F. (2011). How sustainability ratings might deter 'greenwashing': A closer look at ethical corporate communication. Journal of Business Ethics, 102(1), 15-28.Available at: https://doi.org/10.1007/s10551-011-0901-2.

Penny, J. (2012). Value for money and international development: Deconstructing myths to promote a more constructive discussion. OECD Development Co-Operation Directorate.

Penyalver, D., \& Turró, M. (2017). Assessing the fairness of a project financing formula on successive generations. Assessing the Fairness of a Project Financing Formula on Successive Generations, 44(1), 153-176.

Penyalver, D., \& Turró, M. (2018). A classification for the redistributive effects of investments in transport infrastructure. International Journal of Transport Economics, 45(4), 689-726.

Penyalver, D., Turró, M., \& Zavala-Rojas, D. (2018). Intergenerational perception of the utility of major transport projects. Research in Transportation Economics, 70, 97-111.Available at: https://doi.org/10.1016/j.retrec.2017.11.001.

Penyalver, D. (2019). Intergenerational redistributive effects due to the financing formula of investments in transport infrastructure. $A$ microeconomic analysis. Doctoral Program in Transport Engineering and Infrastructure.

Penyalver, D., Turró, M., \& Williamson, J. B. (2019). Measuring the value for money of transport infrastructure procurement; An intergenerational approach. Transportation Research Part A: Policy and Practice, 119, 238-254.Available at: https://doi.org/10.1016/j.tra.2018.11.013.

Poudineh, R., \& Penyalver, P. (2020). Social discount rate and the energy transition policy. Energy Insights, 75, 1-13.

Rendall, M. (2011). Climate change and the threat of disaster: The moral case for taking out insurance at our grandchildren's expense. Political Studies, 59(4), 884-899.Available at: https://doi.org/10.1111/j.1467-9248.2010.00877.x.

Sachs, J. D. (2012). From millennium development goals to sustainable development goals. The Lancet, 379(9832), $2206-2211$.

Sachs, J. D., Schmidt-Traub, G., \& Durand-Delacre, D. (2016). Preliminary sustainable development goal (SDG) index and dashboard. Sustainable Development Solutions Network, 15, 24-27.

Schoenmaker, D., \& Schramade, W. (2018). Principles of sustainable finance (pp. 1-35): Oxford University Press.

Shaoul, J. (2003). A financial analysis of the national air traffic services PPP. Public Money and Management, 23(3), $185-194$.

Slaper, T. F., \& Hall, T. J. (2011). The triple bottom line: What is it and how does it work. Indiana Business Review, 86(1), 4-8.

Stough, R., Vickerman, R., Button, K., \& Nijkamp, P. (2002). Transport infrastructure Cheltenham. En: Classics in transport analysis. Northampton, MA: Elgar Reference Collection.

Thacker, S., Adshead, D., Fay, M., Hallegatte, S., Harvey, M., Meller, H., . . Hall, J. W. (2019). Infrastructure for sustainable development. Nature Sustainability, 2(4), 324-331.

Thomopoulos, N., Grant-Muller, S., \& Tight, M. (2009). Incorporating equity considerations in transport infrastructure evaluation: Current practice and a proposed methodology. Evaluation and Program Planning, 32(4), 35 1-359.Available at: https://doi.org/10.1016/j.evalprogplan.2009.06.013.

Turró, M. (2004). RAILPAG. Railway project appraisal guidelines. European Commission and European Investment Bank. Retrieved from: https://www.eib.org/en/publications/railpag-railway-project-appraisal-guidelines.

Turro, M., \& Penyalver, D. (2019). Hunting white elephants on the road. A practical procedure to detect harmful projects of transport infrastructure. Research in Transportation Economics, 75, 3-20.Available at: https://doi.org/10.1016/j.retrec.2019.03.001.

UK-IPA. (2020). The 2020 Annual report on the government major projects portfolio. The Infrastructure and Projects Authority of UK, Cabinet Office and HM Treasury. Retrieved from: https://www.gov.uk/government/publications/infrastructure-and-projects-authority-annual-report-2020.

United Nations. (2015). Transforming our world: The 2030 Agenda for sustainable development. New York: United Nations: Resolution Adopted by the UN General Assembly.

World Bank. (1997). Handbook on economic analysis of investment operations. Retrieved from: https://www.globalsupportprogramme.org/resources/relevant-reports-and-publications/handbook-economicanalysis-investment-operations.

World Bank Group. (2020). Benchmarking infrastructure development 2020: Assessing regulatory quality to prepare, procure, and manage PPPs and Traditional Public Investment in Infrastructure Projects.

Zeidan, R. (2020). Obstacles to sustainable finance and the covid19 crisis. Journal of Sustainable Finance E Investment, 14.Available at: https://doi.org/10.1080/20430795.2020.1783152. 